\title{
Effect of white kabesak (Acacia leucophloea Roxb) leaves level in the diet on feed intake and body weight gain of Kacang goat
}

\author{
E.D.W. Lawa ${ }^{1,2}$, Marjuki ${ }^{1, *}$, Hartutik ${ }^{1}$ and S. Chuzaemi ${ }^{1}$ \\ ${ }^{1}$ Faculty of Animal Husbandry, Brawijaya University, \\ Jl. Veteran, Malang 65145 - Indonesia \\ ${ }^{2}$ Permanent adress Faculty of Animal Husbandry, Nusa Cendana University, \\ Jl. Adisucipto, Penfui, Kupang-NTT 85001 - Indonesia \\ *Corresponding E-mail:marjuki@ub.ac.id
}

Received July 26, 2017; Accepted September 14, 2017

\begin{abstract}
ABSTRAK
Tujuan penelitian ini adalah untuk menganalisis pengaruh tingkat penggunaan daun kabesak putih (Acacia leucophloea Roxb.) Willd. dalam pakan terhadap konsumsi, kecernaan pakan dan pertambahan bobot badan kambing Kacang. Rancangan Acak Kelompok dengan 5 perlakuan dan 5 ulangan digunakan dalam penelitian ini. Perlakuan tersebut berupa 5 pakan konsentrat yang masing-masing mengandung $0,10,20,30$, dan 40\% daun kabesak putih berdasarkan bahan kering (BK) secara berturutturut sebagai perlakuan $\mathrm{T}_{0}, \mathrm{~T}_{1}, \mathrm{~T}_{2}, \mathrm{~T}_{3}$, dan $\mathrm{T}_{4}$. Semua pakan dibuat dengan kandungan protein kasar $(\mathrm{PK})$ berkisar 11,5-12,5\%. Masing-masing pakan konsentrat diberikan pada 5 ekor kambing Kacang jantan (umur 1-1,5 tahun, berat badan awal 16,7 $\pm 5,0 \mathrm{~kg}$ ) ditambah rumput lapangan kering dengan imbangan 60:40. Hasil penelitian menunjukkan bahwa konsumsi BK, BO dan PK pada kambing yang diberi pakan $\mathrm{T}_{0}$ tidak berbeda nyata dengan kambing yang diberi pakan $\mathrm{T}_{1}$ tetapi lebih tinggi $(\mathrm{P}<0,05)$ dibanding pada kambing yang diberi pakan $\mathrm{T}_{2}, \mathrm{~T}_{3}$ dan $\mathrm{T}_{4}$. Kecernaan $\mathrm{BK}$, BO, PK dan SK serta pertambahan bobot badan kambing yang diberi pakan $\mathrm{T}_{2}$ secara nyata lebih tinggi dan mempunyai konversi pakan lebih baik $(\mathrm{P}<0,05)$ dibanding kambing dengan pakan perlakuan lain. penelitian ini adalah tingkat penggunaan daun kabesak putih yang paling optimal dalam pakan konsentrat adalah sebanyak $20 \%\left(\mathrm{~T}_{2}\right)$.

Kata Kunci: pakan, konsentrat, suplemen, produktivitas, legium pohon
\end{abstract}

\section{ABSTRACT}

This study was conducted to analysis the effect of levels of white kabesak (Acacia leucophloea Roxb.) Willd. leaves in the diet on feed intake, digestibility and body weight gain of Kacang goats. The completely randomized block design using 5 treatments and 5 replications was used in this experiment. The treatments were 5 concentrate feeds containing different levels of white kabesak leaves i.e. 0,10 , 20,30 and $40 \%$ in the dry matter (DM) basis (representing $T_{0}, T_{1}, T_{2}, T_{3}$ and $T_{4}$ treatments, respectively). The feeds were set up to contain $11.5-12.5 \%$ of crude protein (CP). Concentrate feed and native grass was fed at ratio of $60: 40$ was fed to 5 local male goats (age 1-1.5 years old and initial weight of $16.7 \pm 5.0 \mathrm{~kg})$. The results showed that $\mathrm{DM}$, organic matter $(\mathrm{OM})$, and $\mathrm{CP}$ intake of $\mathrm{T}_{0}$ was not significantly different from those of $T_{1}$ goats, but it was significantly higher $(P<0.05)$ than those of $T_{2}, T_{3}$ and $\mathrm{T}_{4}$. The DM, OM, CP, and crude fiber (CF) digestibility as well as body weight gain in $\mathrm{T}_{2}$ goats were significantly higher $(\mathrm{P}<0.05)$ and had feed conversion ratio that was significantly better $(\mathrm{P}<0.05)$ compared to those of the other feed treatments. In conclusion, the most optimum level of white kabesak (Acacia leucophloea Roxb.) Willd. leaves used in concentrate feed for goat was $20 \%$.

Keywords: diet, concentrate, supplement, productivity, tree legumes 


\section{INTRODUCTION}

Productivity of local goats in semi-arid region of East Nusa Tenggara (NTT), Indonesia is considerably very low. Body weight gain of Kacang goats in Timor island of NTT was 25 $\mathrm{g} /$ head/day, which was lower than those of goats in the Western parts of Indonesia $(50 \mathrm{~g} / \mathrm{head} /$ day $)$ and also compared to the goats that are kept under the experiment conditions (157 g/head/day) as reported by Johnson et al. (1986). The main factors causing low goat productivity in those area is due to the low availability and quality of forages which are mostly composed of native grass and crop residues especially in the dry season (Brown et al, 2017). According to Muir et al. (2014) tree legumes may complement the grass-based diet by providing protein during the dry season.

Utilization of feed supplement to the low quality feeds has been reported by many researchers to improve the quality and ruminant productivity. Rodriquez et al. (2014) stated that tropical grass feeding that are generally low in protein content must be supplemented by protein feed in order to improve the productivity of ruminants. The local protein source from forage shrubs and trees can be used to replace imported protein feed such as soybean meal (Traiyakun et al., 2011). Ondiek et al. (2013) reported that leguminous trees and shrubs are potential as protein supplement feeds as these feeds contained high protein and minerals. Ruminant productivity

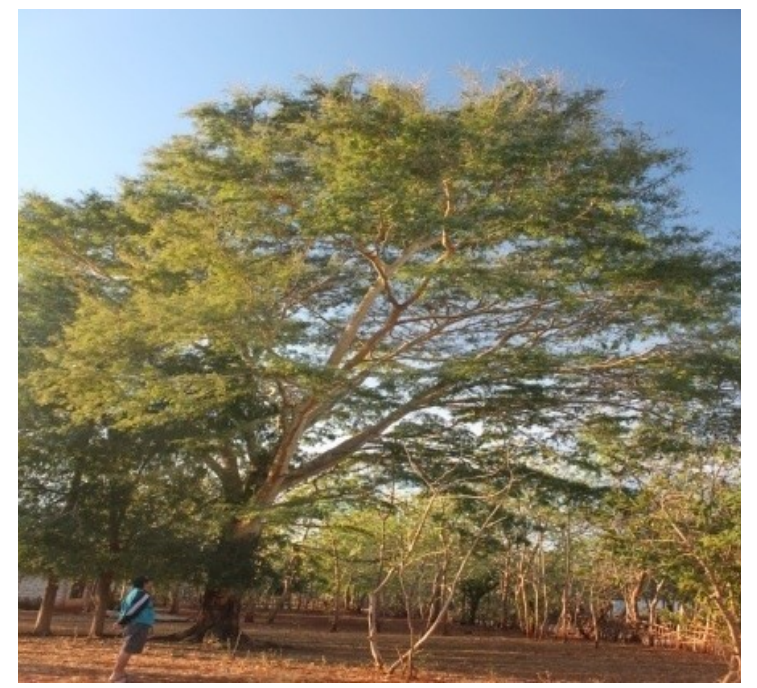

can be improved by combining basal feed with foliage of legume trees and shrubs available in the region as proposed by Olivares-Perez et al. (2011). Legume tree forages are generally a source of better feed quality for grazing and as a supplement to increase the productivity of ruminants fed low-quality feed, especially under harsh environmental conditions (Belachew et al., 2013; Abdalla et al., 2014). Isah et al. (2013) reported that supplementation with legume feeds for goats helped to improve utilization of low quality forage during the dry season. Jamala et al. (2013) and Sollenberger et al. (2014) indicated that leguminous species were contained 25 to $50 \%$ more crude protein than non-leguminous plants because it has capacity to fix atmospheric $\mathrm{N}_{2}$. In addition, Fuah and Pattie (2013) reported that during the dry season, local goat in Timor island fed native grass supplemented with acacia maintained their body weight gain better than goats fed only native grass. Gebeyew et al. (2015) reported that the chemical composition of acacia is an indication of the potenty as feed supplement for livestock production.

White kabesak (Acacia leucophloea, Roxb.) Willd. (Figure 1) is a leguminous trees with an important role as a source of feed for goats and other ruminants on the island of Timor especially during the dry-season. This plant is an endemic plant and grows naturally in the island of Timor and produces leaves (Figure 2) throughout the year. In addition, Orwa et al. (2009) reported that white kabesak is an important source of fodder in

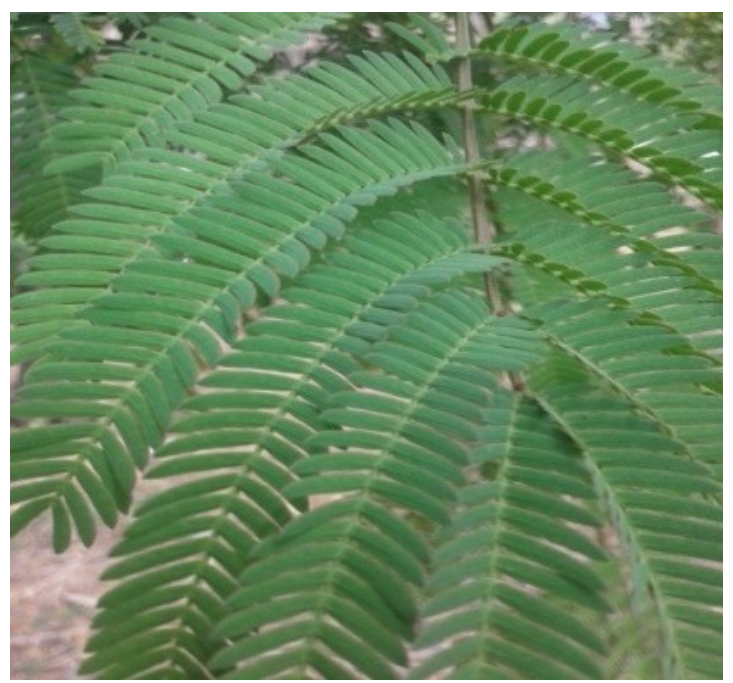

Figure 1 and 2. White Kabesak Tree and Its Leaves (personal document) 
the dry season containing $15 \%$ of crude protein and $18 \%$ of crude fiber. According to Amanullah et al. (2006), the leaves of white kabesak contain DM $31.21 \%$, CP $15.13 \%$, crude fiber (CF) $18.46 \%$ and nitrogen free extract (NFE) $56.11 \%$. White kabesak leaves contain tannin, the anti nutritive factors that may affect the use of feed. Sharifi et al. (2013) reported that the presence of tannins has been associated with lower nutritive value and lower biological availability of macromolecules like proteins and carbohydrates, but Bhat et al. (2013) reported that mixing legumes with grass hay-based diets has been hypothesized as an efficient way of diluting the negative effects of undesirable secondary compounds, such as tannins. However, so far there was no yet scientific data and report about the utilization of white kabesak leaves and its effect on goats performance. Therefore, this study was conducted to evaluate the effect of white kabesak leaves as feed component of diet on feed intake, digestibility of nutrients, body weight gain and feed conversion ratio of Kacang goat.

\section{MATERIALS AND METHODS}

\section{Research Sites}

The research was conducted in the Center for Training Ranch, Agency for Education and Human Resource Development of Agriculture, Ministry of Agriculture, Noelbaki, Kupang, East Nusa Tenggara (NTT).

\section{Research Design}

Twenty-five male Kacang goats aged 1-1.5 years old with an average body weight of block I $=11.82 \mathrm{~kg}$, II $=13.54 \mathrm{~kg}$, III $=15.4 \mathrm{~kg}$, IV $=$ $18.04 \mathrm{~kg}, \mathrm{~V}=24.82 \mathrm{~kg}$ were used in this study. The goats were divided into five groups based on their initial body weight and allotted into a completely randomized block design (Steel and Torrie, 1980) using five treatments and five replications.

\section{Management of Feeding}

The treatments were diet composed of natural grass hay and five different concentrate feeds containing different levels of white kabesak leaves, i.e. $0 \%, 10 \%, 20 \%, 30 \%$, and $40 \%$ in DM basis representing for $\mathrm{T}_{0}$ to $\mathrm{T}_{4}$ diet as treatment, respectively. All diets were formulated to contain 11.5 to $12.5 \%$ of CP (NRC, 2007). Feed composition of each treatment diet is presented in Table 1. The goats were adapted to the treatment diets for two weeks prior to the daily data collection that was done for 75 days.

The data collected in this study were DM, OM, CP and CF intake and digestibility, body weight gain, and feed conversion ratio. Feed offered, refusal and feces of each goat were daily measured and the samples were collected for DM, $\mathrm{OM}, \mathrm{CP}$, and $\mathrm{CF}$ laboratory analysis (AOAC, 2000). Each goat was weighed every week to measure body weight change during the study.

\section{Statistical Analysis}

The data were subjected to analysis of variance according to a completely randomized block design and Duncan's multiple range test using SPSS software for Windows 17 series (Stell

Table 1. Feed Composition of Each Treatment Diet

\begin{tabular}{lccccc}
\hline \multirow{2}{*}{ Feed Ingredients } & \multicolumn{5}{c}{ Treatments } \\
\cline { 2 - 6 } & $\mathrm{T}_{0}$ & $\mathrm{~T}_{1}$ & $\mathrm{~T}_{2}$ & $\mathrm{~T}_{3}$ & $\mathrm{~T}_{4}$ \\
\hline Native grass (\%) & 60 & 60 & 60 & 60 & 60 \\
Soybean meal (\%) & 5.0 & 4.0 & 3.0 & 2.0 & 0.0 \\
Coconut cake (\%) & 8.0 & 6.0 & 5.0 & 4.0 & 0.0 \\
Rice bran (\%) & 15.0 & 10.0 & 7.0 & 2.0 & 0.0 \\
Corn flour (\%) & 12.0 & 10.0 & 5.0 & 2.0 & 0.0 \\
Kabesak white leaves (\%) & 0.0 & 10.0 & 20.0 & 30.0 & 40.0 \\
\hline Total & 100 & 100 & 100 & 100 & 100 \\
\hline
\end{tabular}


and Torrie, 1980) was used in this study.

\section{RESULTS AND DISCUSSIONS}

\section{White Kabesak Leaves}

Table 2 showed that white kabesak leaves collected from those area is fairly good as protein source feed with CP content of $14.72 \%$. The CP content of white kabesak leaves was slightly lower than of reported by Arulnathan and Chellapandian (2016) that was $16.20 \%$. However, the $\mathrm{CP}$ content of white kabesak leaves was lower than $\mathrm{CP}$ content of other leguminous tree leaves, such as Calliandra (18.45\%) (Jayaprakash et al., 2016).

White kabesak leaves contains $0.97 \%$ total tannins with $0.49 \%$ condensed tannins (CT) and total phenol $3.52 \%$. Total tannins, CT and total phenols contents were lower than those in Calliandra calothyrsus (total tannins 5.06-13.3\% DM, CT $3.74 \%$ DM) and Acacia villosa (total tannins $3.21-16.4 \%$ DM, CT $1.26 \%$ DM) as reported by Wina (2010). The CT and total phenol content of Acacia siberiana were 1.68 and $1.63 \% \mathrm{DM}$ ) and those in Acacia hebeclada were 1.56 and $0.58 \%$ DM (Mokoboki, 2011).

\section{Chemical Composition}

All treatment diets contained a comparable $\mathrm{DM}, \mathrm{OM}$, and $\mathrm{CP}$ content (Table 3), but increasing level of white kabesak leaves in the diet $\left(\mathrm{T}_{0}\right.$ to $\left.\mathrm{T}_{4}\right)$ increased slightly $\mathrm{OM}$ and $\mathrm{CF}$ content of the diets. Based on those data, it was shown that white kabesak leaves had potential to be used as concentrate feed component substituting commercial feed protein such as soybean meal, coconut cake, rice bran, and corn flour, which are commonly high in price.

\section{Nutrient Intake, Digestibility, Body Weight Gain and Feed Conversion Ratio}

Data of feeding trial included nutrients intake and digestibility of diet, live weight gain, and feed conversion ratio of goats fed concentrate feed containing different levels of white kabesak leaves were presented in Table 4. The DMI in this study ranged from 49.6 to $68.7 \mathrm{~g} / \mathrm{kg} \mathrm{BW} \mathrm{BW}^{0.75} / \mathrm{d}$ or 2.68 to $3.91 \%$ of body weight from $\mathrm{T}_{4}$ to $\mathrm{T}_{0}$. The DMI was still in the range of those stated by NRC (2006) that was $2-3 \%$ of body weight and those reported by Sultana et al. (2015) that DMI of goats fed on grass supplemented with moringa oleifera was 3.39-3.97\% of body weight. Data on Table 4 showed that increasing level of white kabesak leaves in the diet decreased total DM, $\mathrm{OM}, \mathrm{CP}$ and $\mathrm{CF}$ intake significantly $(\mathrm{P}<0.05)$ and consistently. The highest DM intake was $T_{0}$

Table 2. Proximate Analysis and Tannin Content of White Kabesak Leaves

\begin{tabular}{lc}
\hline \multicolumn{1}{c}{ Parameter } & Content (\%) \\
\hline Dry matter & 90.2 \\
Organic matter & 93,3 \\
Crude protein & 14.7 \\
Crude fiber & 30.4 \\
Ether extract & 0.07 \\
NFE & 48.1 \\
Total Tannins & 0.97 \\
Condensed Tannins & 0.49 \\
Total phenol & 3.52 \\
\hline
\end{tabular}

$\mathrm{NFE}=$ Nitrogen free extract

Table 3. Dry Matter, Organic Matter, Crude Protein and Crude Fiber Content of Each Treatment Diet

\begin{tabular}{lccccc}
\hline \multirow{2}{*}{\multicolumn{1}{c}{ Feed Ingredients }} & \multicolumn{5}{c}{ Treatments } \\
\cline { 2 - 6 } & $\mathrm{T}_{0}$ & $\mathrm{~T}_{1}$ & $\mathrm{~T}_{2}$ & $\mathrm{~T}_{3}$ & $\mathrm{~T}_{4}$ \\
\hline Dry matter (\%) & 89.8 & 89.9 & 89.8 & 89.9 & 90.1 \\
Organic Matter (\% DM) & 87.9 & 87.9 & 88.2 & 88.5 & 88.5 \\
Crude protein (\% DM) & 12.1 & 12.1 & 12.3 & 12.4 & 11.7 \\
Crude fiber (\% DM) & 27.9 & 28.3 & 28.6 & 31.2 & 34.5 \\
\hline
\end{tabular}


Table 4. Average Nutrients Intake, Digestibility, Body Weight Gain and Feed Conversion by Goats Fed on Treatment Diets Containing Different Proportion of Concentrate and White Kabesak Leaves

\begin{tabular}{|c|c|c|c|c|c|}
\hline \multirow[t]{2}{*}{ Variable } & \multicolumn{5}{|c|}{ Treatment } \\
\hline & $\mathrm{T}_{0}$ & $\mathrm{~T}_{1}$ & $\mathrm{~T}_{2}$ & $\mathrm{~T}_{3}$ & $\mathrm{~T}_{4}$ \\
\hline \multicolumn{6}{|l|}{$\begin{array}{l}\text { Nutrient intake }(\mathrm{g} / \mathrm{kg} \\
\mathrm{BW}^{0.75} / \text { day) : }\end{array}$} \\
\hline DMI Native grass & $49.9 \pm 6.56$ & $38.7 \pm 6.98$ & $38.4 \pm 6.06$ & $32.1 \pm 5.92$ & $30.6 \pm 4.22$ \\
\hline DMI Concentrate & $18.8 \pm 0.93$ & $13.8 \pm 1.53$ & $8.78 \pm 1.07$ & $4.74 \pm 0.24$ & 0 \\
\hline DMI White kabesak & 0 & $4.74 \pm 0.53$ & $9.08 \pm 1.10$ & $14.8 \pm 0.72$ & $19.0 \pm 1.53$ \\
\hline Total DMI & $68.7 \pm 7.14^{\mathrm{b}}$ & $57.2 \pm 5.04^{\mathrm{ab}}$ & $56.30 \pm 4.52^{\mathrm{a}}$ & $51.6 \pm 6.22^{\mathrm{a}}$ & $49.6 \pm 5.40^{\mathrm{a}}$ \\
\hline OMI Native grass & $42.9 \pm 4.49$ & $33.3 \pm 6.21$ & $33.30 \pm 5.41$ & $27.6 \pm 5.40$ & $26.4 \pm 3.77$ \\
\hline $\mathrm{OMI} \mathrm{Co}$ & $17.4 \pm 0.86$ & $12.7 \pm 1.41$ & $8.14 \pm 0.99$ & $4.39 \pm 0.22$ & 0 \\
\hline OMI White kabesak leaves & 0 & $4.43 \pm 0.49$ & $8.43 \pm 1.03$ & $13.8 \pm 0.67$ & $17.8 \pm 1.43$ \\
\hline Total OMI & $60.3 \pm 15.05^{\mathrm{b}}$ & $50.40 \pm 4.41^{\mathrm{ab}}$ & $49.9 \pm 4.01^{\mathrm{a}}$ & $45.8 \pm 5.68^{\mathrm{a}}$ & $44.2 \pm 4.86^{\mathrm{a}}$ \\
\hline CPI Native grass & $3.83 \pm 1.27$ & $2.96 \pm 0.54$ & $2.94 \pm 0.46$ & $2.46 \pm 0.45$ & $2.35 \pm 0.33$ \\
\hline CPI Conc & $3.50 \pm 0.17$ & $3.28 \pm 0$ & $3.31=$ & $3.17 \pm 0.26$ & 0 \\
\hline CPI White kabesak leaves & 0 & $0.70 \pm 0.07$ & $1.44 \pm 0.06$ & $2.04 \pm 0.12$ & $2.80 \pm 0.23$ \\
\hline Total CPI & $7.33 \pm 1.38^{\mathrm{b}}$ & $6.94 \pm 0.17^{b}$ & $7.69 \pm 0.56^{\mathrm{a}}$ & $7.66 \pm 0.60^{\mathrm{b}}$ & $5.15 \pm 0.51^{\mathrm{a}}$ \\
\hline CFI Native grass & $20.3 \pm 5.50$ & $17.0 \pm 1.97$ & $16.90 \pm 2.06$ & $14.6 \pm 2.68$ & $8.10 \pm 1.62$ \\
\hline CFI Concentrate & $1.95 \pm 0.10$ & $1.45 \pm 0.16$ & $0.87 \pm 0.11$ & $0.46 \pm 0.03$ & 0 \\
\hline CFI White kabesak leaves & 0 & $1.44 \pm 0.16$ & $2.76 \pm 0.33$ & $4.48 \pm 0.22$ & $5.79 \pm 0.47$ \\
\hline Total CFI & $22.3 \pm 5.56^{\mathrm{b}}$ & $19.90 \pm 1.67^{b}$ & $20.50 \pm 1.81^{b}$ & $19.50 \pm 2.75^{b}$ & $13.90 \pm 1.91^{\mathrm{a}}$ \\
\hline \multicolumn{6}{|l|}{ Digestibility of nutrients: } \\
\hline DM digestibility (\%) & $69.3 \pm 7.76^{\mathrm{ab}}$ & $69.8 \pm 5.12^{\mathrm{b}}$ & $75.7 \pm 4.89^{b}$ & $63.8 \pm 6.96^{\mathrm{a}}$ & $67.1 \pm 6.44^{\mathrm{a}}$ \\
\hline OM digestibility(\%) & $68.9 \pm 7.71^{\mathrm{ab}}$ & $69.7 \pm 4.78^{\mathrm{ab}}$ & $75.3 \pm 5.10^{\mathrm{b}}$ & $62.8 \pm 7.20^{\mathrm{a}}$ & $66.4 \pm 6.78^{\mathrm{a}}$ \\
\hline CP digestibility (\%) & $77.8 \pm 7.20^{\mathrm{b}}$ & $77.5 \pm 4.36^{\mathrm{b}}$ & $82.4 \pm 4.91^{b}$ & $75.4 \pm 5.54^{\mathrm{b}}$ & $65.9 \pm 4.97^{\mathrm{a}}$ \\
\hline CF digestibility (\%) & $63.3 \pm 10.5^{\mathrm{b}}$ & $66.5 \pm 6.29^{b c}$ & $73.6 \pm 6.32^{\mathrm{c}}$ & $61.5 \pm 7.71^{b}$ & $52.0 \pm 12.3^{\mathrm{a}}$ \\
\hline \multicolumn{6}{|l|}{$\begin{array}{l}\text { Digestible nutrients intake } \\
\left(\mathrm{g} / \mathrm{kg} \mathrm{BW}^{0.75} / \mathrm{d}\right) \text { : }\end{array}$} \\
\hline DDMI & $47.4 \pm 2.34^{b}$ & $39.9 \pm 4.20^{\mathrm{ab}}$ & $42.5 \pm 3.50^{\mathrm{ab}}$ & $33.1 \pm 7.05^{\mathrm{a}}$ & $33.4 \pm 5.88^{\mathrm{a}}$ \\
\hline DOMI & $41.4 \pm 0.78^{\mathrm{c}}$ & $35.1 \pm 3.41^{\mathrm{ab}}$ & $37.5 \pm 3.14^{\text {bc }}$ & $28.9 \pm 6.40^{\mathrm{a}}$ & $29.4 \pm 5.34^{\mathrm{a}}$ \\
\hline DCPI & $5.71 \pm 1.52^{\mathrm{b}}$ & $5.38 \pm 0.53^{\mathrm{b}}$ & $6.03 \pm 0.39^{b}$ & $5.93 \pm 0.66^{\mathrm{b}}$ & $3.39 \pm 0.43^{\mathrm{a}}$ \\
\hline DCFI & $13.9 \pm 3.92^{\mathrm{b}}$ & $13.2 \pm 1.38^{\mathrm{b}}$ & $15.10 \pm 1.65^{\mathrm{b}}$ & $12.10 \pm 2.98^{b}$ & $7.31 \pm 2.51^{\mathrm{a}}$ \\
\hline DMI (g/h/d) & $466.18 \pm 3.20$ & $459.10 \pm 3.19$ & $458.90 \pm 3.26$ & $443.29 \pm 5.04$ & $434.89 \pm 5.51$ \\
\hline BWG (g/h/d) & $65.20 \pm 4.57^{\mathrm{bc}}$ & $64.03 \pm 4.84^{b c}$ & $66.7 \pm 6.27^{\mathrm{c}}$ & $62.70 \pm 5.54^{\mathrm{b}}$ & $56.70 \pm 6.64^{\mathrm{a}}$ \\
\hline Feed conversion & $7.15 \pm 0.70^{\mathrm{bc}}$ & $7.14 \pm 0.66^{b}$ & $6.88 \pm 0.52^{\mathrm{a}}$ & $7.07 \pm 0.91^{b}$ & $7.67 \pm 0.83$ \\
\hline
\end{tabular}

a, b, c Means within same row with different superscripts were significantly different $(\mathrm{P}<0.05)$.

$\mathrm{DMI}=$ Dry matter intake, $\mathrm{OMI}=$ organic matter intake, $\mathrm{CPI}=$ crude protein intake, $\mathrm{CFI}=$ crude fiber intake, DDMI $=$ digestible dry matter intake, DOMI $=$ digestible organic matter intake, DCPI $=$ digestible crude protein intake, $\mathrm{DCFI}=$ digestible crude fiber intake, $\mathrm{BWG}=$ body weight gain 
$\left(68.7 \pm 7.14 \mathrm{~g} / \mathrm{kg} \mathrm{BW}^{0.75} /\right.$ day) and the lowest was $\mathrm{T}_{4}\left(49.6 \pm 5.40 \mathrm{~g} / \mathrm{kg} \mathrm{BW} \mathrm{B}^{0.75} /\right.$ day $)$. The decrease of those nutrients intake was not only due to the decrease of concentrate feed intake but more importantly also due to the decrease of native grass intake as a basal diet. The decrease of nutrients intake due to the increase of white kabesak leaves level in the concentrate feed was mostly due to the increase of anti nutritive factors (phenolic compound) and CF. Abdu et al. (2012) stated that the presence of anti nutritive factors especially condensed tannin in some tree leaves decreased feed intake and livestock performance, mainly when the tree leaves are fed in large quantity. However Sedighi-Vesagh et al. (2015) reported feeding diet containing 32\% Pistachioby product was not affect significantly by DMI of goat.

Significant and decreasing of DM, OM, CP, and $\mathrm{CF}$ digestibility and consequently intake of digestible $\mathrm{DM}, \mathrm{OM}, \mathrm{CP}$, and $\mathrm{CF}$ took place also due to the increase of level of white kabesak leaves in the diet from $T_{0}$ to $T_{4}$. However, the increase of level of white kabesak leaves in the diet from $T_{0}$ to $T_{4}$ affected significantly but not consistently body weight gain, and feed conversion. Body weight gain increased and feed conversion decreased from $T_{0}$ to $T_{2}$, but body weight gain decreased and consequently feed conversion increased from $\mathrm{T}_{3}$ to $\mathrm{T}_{4}$. In the other words, goat fed on diet containing $20 \%$ white kabesak leaves $\left(\mathrm{T}_{2}\right)$ showed significantly $(\mathrm{P}<0.05)$ highest body weight gain and the lowest feed conversion compared to other treatment feeds. These phenomenon on all variables was most presumably due to the increase of tannin or total phenolic content of the diet with the increase of level of white kabesak leaves in the diet. Sandoval-Castro et al. (2005) reported that phenolic compounds, alkaloids, tannins and aromatic compounds in the diet are known to depress feed palatability hence decreased feed intake, regardless the nutrients content of the feed. Lamy et al. (2011) reported that selection of cattle to feed depends mainly on the palatability of the feed and tannins are usually associated with the decrease of palatability which results in decreased vigor grazing of livestock.Total tannin content of white kabesak leaves in this study is $0.97 \%$ and condensed tannin is $0.49 \%$ it means that total condensed tannins intake by goat in this research increased from $0 ; 0.20 \pm 0.03 ; 0.41 \pm 0.06 ; 0.61 \pm$ 0.09 ; and $0.82 \pm 0.13 \mathrm{~g} / \mathrm{kg} \mathrm{DM}$ from $\mathrm{T}_{0}$ to $\mathrm{T}_{4}$, respectively. According Amanullah et al. (2006) and Orwa et al. (2009) white kabesak leaves were poorly given as a single feed for ruminants because it contains fairly nutritious. In addition lower body weight gain on treatment $T_{3}$ and $T_{4}$ must also be caused by lower feed intake and digestibility as also reported by Pineiro-Vasquez et al. (2015).

The results of this study were not different from those reported by Traiyakun et al. (2011) in goats given feed containing different levels of lamtoro leaf meal $0,25,50$ and 75 percent as a substitute for soybean meal in feed concentrates; but lower than the goats given legume leaf of Serecia terminalia, Combretum apiculatum and Eulea schimperi as a supplement in the buffel grass basal ration (Aganga and Monyatsiwa, 1999). OM, CP, and CF intake showed also the same phenomenon with the dry material in which the control treatment showed significantly higher consumption than the treatment using white kabesak leaves.

Average body weight gain of goats was significantly $(\mathrm{P}<0.05)$ influenced by the use of white kabesak leaves in feed. Goats fed on feed containing $20 \%$ white kabesak leaves $\left(\mathrm{T}_{2}\right)$ showed the highest body weight gain followed by goats that received rations $T_{0}, T_{1}, T_{3}$ and $T_{4}$. The results of this study were similar to that found by Mousa (2011) who reported that the use of acacia forage in the ration of growing sheep up to $40 \%$ improved growth performance, economic efficiency, carcass percentage and lower feed costs per $\mathrm{kg}$ of body weight. Abegunde et al. (2017) found the best level of combination of Tithonia diversivolia and Veronia amygdalyna in the concentrate feed of $10 \%$ as feed supplement for low quality grass fed to goat. Even Rahman et al. (2015) concluded from their research that supplementation with green trees in the feeding system of goats produced higher weight gain, digestibility and nitrogen balance than goats fed on only grass.

\section{CONCLUSION}

The use of white kabesak leaves in the diet of goats at level of $20 \%$ showed the best results in feed intake, digestibility, body weight gain and feed conversion.

\section{REFERENCES}

Abdallah, M.S., I.A. Babiker, J.S. Al-Abrahim, A.E. Mohammed, M.M. Elobeid and K.F. 
Elkhalifa. 2014. Fodder potential and chemical composition of Acacia nilotica fruits for livestock in the drylands of Sudan. Int. J. Plant, Anim. and Environt. Sci.. 4 (1): 366-369.

Abdu, S.B., M.R. Hasan, H.Y. Adamu, S.M. Yashimi and M.J. Abdullahi. 2012. Intake, nutrient digestibility and nitrogen balance of Acacia auriculate, Gmelina arborea, Albizia lebbeck and Butryos permum parkii by Yankasa bucks. Iranian J. Appl. Anim. Sci. 2 (2): 121-125.

Abegunde, T.O., F.T. Ajayi, J.F. Olona and F. Balogun. 2017. Supplemental value of leaf based concentrates with Panicum maximum hay on performance of West African Dwarf goats. Afr. J. Agric. Res. 12 (9): 723-729.

Aganga, A.A. and C.B. Monyatsiwa. 1999. Use of browses (Terminalia serecia, Conbretum apiculatum or Euclea schrimperi) as supplement for growing Tsawana goats. Trop. Anim. Health Prod. 31: 295-305.

Amanullah, M.M., E. Somasundaram, A. Alagesan, K. Vaiyapuri, S. Pazhanivelan and K. Sathyamoorthi. 2006. Evaluation of some tree species for leaf fodders in Tamil Nadu. Res. J. Agric. Biol. Sci. 2(6):552-553.

AOAC (Association of Official Analytical Chemists). 2000. Official Methods of Analysis, $17^{\text {th }}$ Edition. AOAC: Washington, DC.

Arulnathan, N. and M. Chellapandian. 2016. Chemical composition of thorney tree leaves available during dry season in North Western zone of Tamil Nadu for goats. Int. J. Sci. Environt. Technol. 5(3):1381-1383.

Belachew, Z., K. Yisehak, T. Taye and G.P.C. Janssens. 2013. Chemical composition and in sacco ruminal degradation of tropical trees rich in condensed tannins. Czech. J. Anim. Sci. 58(4):176-192.

Bhat, T.K., A. Kannan, B. Singh and O.P. Sharma. 2013. Value addition of feed and fodder by allevating the anti-nutritional effects of tannins. Agric. Res. 2:189-206.

Brown, D., J.W. Ng'ambi and D. Norris. 2017. Effect of tanniniferous acacia karroo leaf meal inclusion level on fed intake, digestibility and live weight gain of goats fed a setaria verticillata grass hay-based diet. J. Appl. Anim. Res. (online), 1-6.

Fasae, O.S and J.A. Alokan. 2006. Growth performance of weaner Yankassa sheep fed varying levels of Leucaena leucocephala leaf residues. ASSES SERIES A6. 2:323328.

Fuah, A.M. and W.A. Pattie. 2013. Productivity of local goats supplemented with Acacia villosa and Corypha gebanga. Med. Pet. 36(1): 4044.

Gebeyew, K., K. Beriso, A. Mohamed, G.G/silassie and S. Melaku. 2015. Review on the nutritive value of some selected acacia species for livestock production in dry land areas. J. Adv. Dairy Res. 3:139.

Isah, O.A., S.A. Oguntuyo, O. Dawodu, O.O. Diya, M.O. Afolabi and L.A. Ominiyi. 2013. Feed utilization, rumen parameters and microbial profile of goats fed different tropical browse plants with Pennisetum purpureum as basal diet. The Pacific J. Sci. Technol. 14:397-405.

Jamala, G.Y., I.L. Tarinbuka, D. Moris and S. Mahai. 2013. The scope and potentials of fodder trees shrubs in agroforestry. IOSRJAVS. 5:11-17.

Jayaprakash, G., K. Shyama, P. Gangadevi, K. Ally, K.S. Anil, K. A. K. Raj, M. Sathiyabarathi and M.A. Robert. 2016. Biomass yield and chemical composition of calliandra calothyrsus, Desmanthus virgatus and Stylosanthes hamata. Int. J. Sci, Environt. and Technol. 5 (4):2290-2295.

Johnson, W.L., J.A. Van Eys and H.A. Fitzhugh. 1986. Sheep and goats in tropical and subtropical agricultural systems. J. Anim Sci. 63:1587-1599.

Lamy, E., H. Rawel, F.J. Schweigert, F.C.E. Silva, A. Ferreira, A. R. Costa, C. Antunes, A.M. Almeida, A.V. Coelho and E. Sales-Baptista. 2011. The effect of tannins on Mediterranean ruminant ingestive behavior: The role of the oral cavity. Molecules. 16:2766-2784.

Mokoboki, H.K. 2011. Effect of species within season on techniques used to measure nutritive value and anti-nutritional factors in browse tree leaves. Life Sci. Journal. 8 (52):112-119

Mousa, M.R.M. 2011. Effect of feeding acacia as supplements on the nutrient digestion, growth performance, carcass traits and some blood constituents of Awassi lambs under the conditions of North Sinai. Asian J. Anim. Sci. 5(2):102-117.

Muir, J.P., W.D. Pitman, J.C.B. Dubeux, Jr. and J.L. Foster. 2014. The future of warmseason, tropical and subtropical forage 
legumes in sustainable pastures and ranglands. African. J. Range \& Forage Sci. 31:187-198.

National Research Council. 2006. Nutrient requirements of sheep and goats. Committee on Nutrient Requirement of Small Ruminants. National Academies Press, Washington DC.

National Research Council. 2007. Nutrient Requirement of Small Ruminant. National Academic Press.

Olivares-Perez, J., F. Aviles-Nova, S. RojasHernandez, B. Albarran-Portilo and O.A. C.Ortega. 2011. Identification uses and measurement of foffers legumes trees in southfarmers of the State of Mexico. Tropical and Subtropical Agroecosystems. 14:739-748.

Ondiek, J.O., P.B. Ogore, E.K. Shakala and G.M. Kaburu. 2013. Feed intake, digestibility and performance of growing small East African goats offered maize (Zea mays) stover supplemented with Balanites aegyptiaca and Acacia tortilis leaf forages. Basic Res. J. Agric. Sci. Rev. 2 (1) : 21-22.

Orwa, C., A. Mutua, R. Kindt, R. Jamnadass and A. Simons. 2009. Agroforestree database: a tree reference and selection guide version 4.0. World Agroforestry Centre, Kenya.

Pinero-Vazquez, A.T., J.R. Canul-Solis, J.A. Alayon-Gamboa, A.J. Chay-Canul, A.J. Ayala-Burgos, C.F. Aguilar-Perez, F.J. Solorio-Sanchez and J.C. Ku-Vera. 2015. Potential of condensed tannins for the reduction of emission of enteric methane and their effect on ruminant productivity. Arch. Med. Vet. 47:263-272.

Rahman, Z., A. Akbar, A. Hossain and Y. Ali. 2015. Effect of tree forage supplementation on growth performance of goats. Asian J. Med. Biol. Res. 1(2):2009-2015.

Rodriquez, R., N. Gonzalez, A. Ramirez, S. Gomes, O. Moreira, L. Sarduy and Y. Medina. 2014. Tannins of tropical shurb like legumes: their effect on protein protection of soybean meal. Cuban J. Agric. Sci. 48(3): 247-252.

Sandoval-Castro, C.A., H.L. Lizarraga-Sanchez and F.J. Solorio-Sanchez. 2005. Assesment of tree fodders preference by cattle using chemical composition, in vitro gas production and in situ degradability. Anim. Feed Sci. Technol. 123-124:277-289.

Sedighi-Vesagh, R., A.A. Naserian., M.H. Ghaffari and H.V. Petit. 2015. Effects of Pistachio by-product on digestibility, milk production, milk fatty acids profile and blood metabolites in Saanen dairy goats. Anim. Physiol. Anim. Nutr. 99: 777-787.

Sharifi, M., A.A. Naserin and H. Khorasani. 2013. Effect of tannin extract from Pistachiobyproduct on in vitro gas production. Iranian J. Appl. Anim. Sci. 3 (4): 667-671.

Sollenberger, L.E., J.C.B. Dubeux, Jr. and J.P. Muir. 2014. Establishment and management of legume-grass pastures. In : O.G. Pereira, D.M. da Fonseca, K.G. Ribeiro, F.H.M. Chizzotti (eds.), 7th Symposium on Strategic Management of Pasture/5th International Symposium on Animal Production Under Grazing. Visconde do Rio Branco: Superma 2014. P. 135-178.

Sultana, N., A.R. Alimun, K.S. Huque, M. Baba and J. Hossain. 2015. Evaluation of Moringa foliage (Moringa oleifera) as goat fed. Iranian J. Appl. Anim. Sci. 5 (4): 865-871.

Steel, R.G.D. and J.H. Torrie. 1980. Principles and Procedures of Statistics with Special Reference to the Biological Sciences. McGraw Hill, New York.

Traiyakun, S., W. Harakord, C. Yuangklang and P. Paengkoum. 2011. Leucaena leucocephala meal as replacement to soybean meal in growing goat diets. J. Agric. Sci. Technol. A. $1: 1150-1154$.

Wina, E. 2010. Utilization of tannin containing shrub legumes for small ruminant production in Indonesia. Wartazoa. 20(1): 21-30. 